Research Article, Issue 1
Analytical Methods in Environmental Chemistry Journal
AMECJ

\title{
Environmental Health: Evaluation of heavy metals pollution in Isfahan industrial zone from soils, well / eluent waters and waste water by microwave- electro-thermal atomic absorption spectrometry
}

\author{
Shahnaz Teimooria," \\ ${ }^{a}$ Department of Environment and Natural Resources, Islamic Azad University, Science and Research Branch, Tehran, Iran
}

\section{A R T I C L E I N F O:}

Received 1 Jan 2019

Revised form 24 Feb 2019

Accepted 8 Mar 2019

Available online 20 Mar 2019

Keywords:

Heavy Metals

Environmental Pollution

Waters and Soils

Electro-thermal Atomic

Absorption Spectrometry

\begin{abstract}
A B S T RA C T
In this study, soils, well waters, drinking waters, and waste water in the Isfahan industrial area were sampled in spring and summer 2018. In 8 points of industrial zone, important toxic heavy metals such as, lead $(\mathrm{Pb})$, Cobalt $(\mathrm{Co})$, Nickel $(\mathrm{Ni})$, Chromium $(\mathrm{Cr})$, and Cadmium $(\mathrm{Cd})$ were sampled from surface soil (up to $2 \mathrm{~m}$ ), well/drinking waters and waste water. After sample preparation with micro-wave digestion technique, the concentration of heavy metals was determined by electro-thermal atomic absorption spectrometry (ET-AAS). According to the well water analysis, the mean concentration of $\mathrm{Cr}, \mathrm{Ni}, \mathrm{Co}, \mathrm{Cd}$, and $\mathrm{Pb}$ in well water were $95 \mu \mathrm{g}$ $\mathrm{L}^{-1}, 146 \mu \mathrm{g} \mathrm{L}^{-1}, 185 \mu \mathrm{g} \mathrm{L}{ }^{-1}, 12 \mu \mathrm{g} \mathrm{L}^{-1}$, and $11 \mu \mathrm{g} \mathrm{L}{ }^{-1}$, respectively. In well water, the concentrations of $\mathrm{Cd}, \mathrm{Ni}, \mathrm{Cr}$ and $\mathrm{Co}$ were found much higher than $\mathrm{Pb}$ in comparison with the references of World Health Organization (WHO). Also, the concentrations of such elements in soils and drinking waters are less and near found in accordance to EPA and WHO references respectively. In addition, the concentration of metals in waste water of industrial area was more than well waters. Therefore, the pollution of heavy metals such as $\mathrm{Cr}, \mathrm{Co}, \mathrm{Cd}$, and $\mathrm{Ni}$ in wastewaters of industries can be diffused to well waters and eluent waters in this region and cause many problems in plants and humans.
\end{abstract}

\section{Introduction}

Heavy metals are a group of elements with a mass density greater than $4.5 \mathrm{~g} \mathrm{~cm}^{-3}$, which tend to release electrons in chemical reactions and form simple cations. Heavy metals such as, $\mathrm{Cd}, \mathrm{Ni}, \mathrm{Co}, \mathrm{Cr}$, and $\mathrm{Pb}$ is potentially toxic; in addition, their effects in water, plants, and soil are very important. Prolonged accumulation of heavy metals through food stuff may lead to chronic effect in the nerve system, kidney and liver of humans [1-4]. The sources of anthropogenic contamination or pollution of the

\footnotetext{
*Corresponding Author: Shahnaz Teimoori

E-mail: sht9737@gmail.com

DOI: https://doi.org/10.24200/amecj.v2.i01.44
}

environment by heavy metals include different branches of industry, the power industry, transport, municipal waste management, waste dumping sites, fertilizers and waste used to fertilize soil. The heavy metals from these sources are dispersed in the environment and they contaminate soil and water. They also (directly or indirectly through plants) get into human and animal bodies. After entering heavy metals from water or soil to vegetables these metals can enter people's diet and consequently exert their effects. Soil chemical composition plays important role in composition of plant materials. Overall toxic metal availability in soil contributes to metal contents in vegetables. Soil eco-system throughout 
world has been contaminated with heavy metals by various human activities and movement of metals in food chain has become human health hazard $[5,6]$. Nickel does not bio-accumulate to a great extent in animals. There is evidence of uptake and accumulation in certain plants. Nickel food intake in the United States ranges is between 69 and $162 \mu \mathrm{g}$ per day for adults. The standard of United Nations Food for irrigation water is $200 \mu \mathrm{g} \mathrm{L} \mathrm{L}^{-1}$. The US EPA primary drinking water standard is $0.1 \mathrm{mg}$ $\mathrm{L}^{-1}$ [7]. The trace amount of nickel and cobalt, are indicated to be either necessary or toxic depending on their environment concentration range. For example, due to studies on chicks and rats, nickel is apparently essential for proper liver function, or cobalt is at the core of a vitamin B12. On the other hand, some of nickel and cobalt compounds are carcinogenic [8-10]. Lead is a common industrial toxin and environmental pollutant and can enter the human body. It can affect the nervous system significantly, especially on the central nervous system. Industrial development has paid attention to the adverse effects of lead pollution on people's health [11]. A series of literatures also showed that even if children's blood lead levels below 10 $\mu \mathrm{g} \mathrm{dL} \mathrm{d}^{-1}$, they can appear significant neurological dysfunction. Some researchers showed that many rivers had lost its self-purification capacity because of receiving so many industrial wastewaters [12-14]. Cadmium is highly toxic and has been implicated in some cases of poisoning through food. Minute quantities of cadmium are suspected of being responsible for adverse changes in arteries of human kidneys. The FAO-recommended maximum level for cadmium for irrigation water is $10 \mu \mathrm{g} \mathrm{L}^{-1}$. USEPA drinking water standard for cadmium is $0.005 \mathrm{mg} \mathrm{L}^{-1}$ [15]. Chromium can enter the human body through breathing, food and drinking water. Chromium salts are used extensively in industrial processes and may enter a water supply through the discharge of wastes. Chromium may exist in water supplies in both the hexavalent and the trivalent state although the trivalent form rarely occurs in potable water. USEPA drinking water standard for chromium and FAO recommended the maximum limit for irrigation water as $100 \mu \mathrm{g} \mathrm{L}^{-1}$ [16]. The World Health Organization (WHO) states that the guideline values of $50 \mu \mathrm{g} . \mathrm{L}^{-1} \mathrm{Cr}(\mathrm{VI})$ are considered to be too high as compared to its Geno toxicity [1719]. Thus it is obvious that determination of heavy metals, at trace level, in water and environmental samples is of great significance from the public health and environmental point of view. Wastewater irrigation has been practiced widespread in the world [20, 21]. Wastewater irrigation creates both opportunities and problems in agricultural source [22]. It provides important water resources and has the beneficial aspects of adding valuable plant nutrients and organic matter to soil [23]. However, excessive accumulation of heavy metals in agricultural soil through wastewater irrigation may not only result in soil contamination, but also affect food quality and safety [24]. It is necessary and important to develop sensitive methods for determining heavy metals in soil, and water samples and then, the results must be compared with World Health Organization (WHO) and Environmental Protection Agency (EPA) [25, 26]. Various techniques such as, inductively coupled plasma mass spectrometry [27,28], flame atomic absorption spectrometry (F-AAS) [29], electrothermal atomic absorption spectrometry (ETAAS) [30,31] and cold vapor atomic absorption spectrometry(CV-AAS) [32] have been applied for the determination of soil and water samples.

The aim of this study was to monitor the toxic heavy metals such as, $\mathrm{Cd}, \mathrm{Cr}, \mathrm{Ni}, \mathrm{Co}$, and $\mathrm{Pb}$ in well waters, drinking waters, waste waters and soils in Isfahan's industrial regions and evaluation of environmental pollution in this area. After microwave digestion of samples the concentration of heavy metals were determined by ET-AAS. The results of data were analyzed using SPSS statistical programmer, PHSTAT, and excel computer packages.

\section{Experimental procedure}

\subsection{Apparatus and materials}

Determination of heavy metals $(\mathrm{Cd}, \mathrm{Cr}, \mathrm{Ni}, \mathrm{Co}$, $\mathrm{Pb}$ ) was performed with a spectra GBC electrothermal atomic absorption spectrometer (Plus 
Table 1. The instrumental conditions of ET-AAS for determination heavy metals.

\begin{tabular}{llllll}
\hline Element & Cd & Co & Cr & Ni & Pb \\
\hline Lamp current $(\mathrm{mA})$ & 4 & 7 & 7 & 4 & 5 \\
Wave length $(\mathrm{nm})$ & 228.8 & 240.7 & 357.9 & 232.0 & 217.0 \\
Slit width $(\mathrm{nm})$ & 0.5 & 0.2 & 0.2 & 0.2 & 1.0 \\
LOD $\left(\mu \mathrm{g} \mathrm{L}^{-1}\right)$ & 0.05 & 0.6 & 0.1 & 0.8 & 0.25 \\
LOQ $\left.\left(\mu \mathrm{g} \mathrm{L}^{-1}\right)\right)$ & 0.2 & 3 & 1 & 5 & 3 \\
Working range & $0.2-1.8$ & $3-45$ & $1-16$ & $5-65$ & $3-40$ \\
\hline
\end{tabular}

932, Australia) using a graphite furnace module (GF3000, GBC). The operating parameters for the metal of interest were set as recommended by the manufacturer. All samples in ET-AAS were performed using $20 \mu \mathrm{L}$ of samples. The $\mathrm{pH}$ values of the solutions were measured by a digital $\mathrm{pH}$ meter (Metrohm 744). Microwave digestions were carried out with a Multi-wave 3000 (Anton Paar, $100 \mathrm{~mL}, 20$ bar; Austria). The instrumental and temperature programming for the graphite atomizer are listed in Table 1 and 2. All reagents were of ultra-trace analytical grade from Merck Germany. $\mathrm{Cd}, \mathrm{Cr}, \mathrm{Ni}, \mathrm{Co}$ and $\mathrm{Pb}$ stock solution was prepared from an appropriate amount of the nitrate salt of this analyte as $1000 \mathrm{mg} \mathrm{L}^{-1}$ solution in $0.01 \mathrm{~mol} \mathrm{~L}^{-1}$ HNO3 (Merck). Standard solutions were prepared daily by dilution of the stock solution. Ultrapure water $(18 \mathrm{M} \Omega . \mathrm{cm})$ was obtained from Millipore Continental Water System (Bedford, USA).

\subsection{Sampling}

In this study, $\mathrm{Cr}, \mathrm{Co}, \mathrm{Ni}, \mathrm{Cd}$ and $\mathrm{Pb}$ of soil, well water and drinking in eight different location of Isfahan industrial area were evaluated. For sampling, all glass tubes were washed with a $1 \mathrm{~mol}$ $\mathrm{L}^{-1} \mathrm{HNO}_{3}$ solution for at least $24 \mathrm{~h}$ and thoroughly rinsed 8times with ultrapure water before use. As determination of heavy metals concentration in soil samples are very difficult, even contamination at any stage of sampling, sample storage and handling or analysis has the potential to affect the accuracy of the results. All samples prepared in the vicinity of Isfahan industries. Soil and water were sampled from eight points of Isfahan's industrial zone. All of samples prepared from south of Isfahan province $(4 * 4 \mathrm{~km} 2)$ (Fig.1). Due to large study area Global Positioning System (GPS) was used to determine the actual coordinates of the sampling sites and to reconfirm the location of the sampling site during subsequent sampling periods.

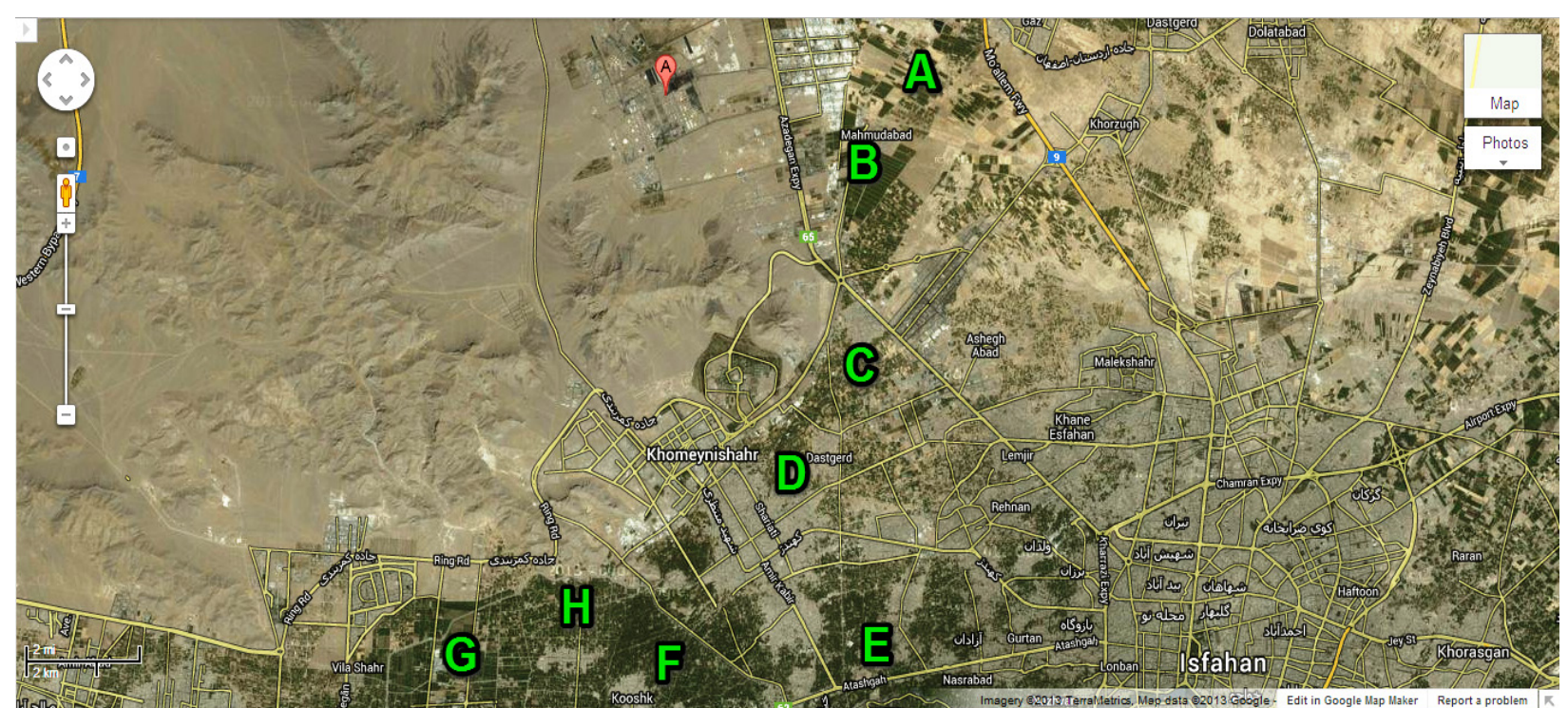

Fig 1. Sampling water and soil in the Isfahan oil refinery area, and G point is oil refinery. 
Table 2. temperature programming for the graphite atomizer of ET-AAS

\begin{tabular}{|l|l|l|l|l|l|}
\hline Element & Cd & Co & Cr & Ni & Pb \\
\hline Drying & 130 & 130 & 130 & 130 & 130 \\
Ashing & 300 & 800 & 1100 & 900 & 400 \\
Atomization & 1800 & 2300 & 2500 & 2400 & 2000 \\
\hline
\end{tabular}

In preliminary studies soil and water investigation consists of eight locations, in order to determine and to provide ground information for subsequent detailed planning of the future work. For soil sampling multiple sub samples were taken from each location and then samples were homogenized into composite sample with stainless spoon and then sub sampled by spoon into each sample container to get accurate results.

\subsection{General procedure}

Five samples of well/drinking water $(16 \times 5)$, wastewaters $(10)$ and soil $(8 \times 5)$ were collected from eight Isfahan's industrial region $(\mathrm{N}=130)$. Samples were placed in polyethylene bags and brought to laboratory of IPIHR for analysis. All samples were washed with tap water followed with DDW (double de-ionized distil water). In the laboratory, the soil samples after air drying at room temperature were sieved with nylon mesh $(2 \mathrm{~mm})$. The $<2 \mathrm{~mm}$ fraction was grinded in an agate and pestle and passed through a 63 micron sieve. Selected physiochemical properties of these soils were analyzed using standard methods. Soil $\mathrm{pH}$ was measured in suspension of soil to water ratio (1:2) using calibrated $\mathrm{pH}$ meter. Briefly, $1 \mathrm{~g}$ of the soil sample was placed in a decomposition polyethylene tube to which was added $1 \mathrm{~mL}$ of $10 \%(\mathrm{w} / \mathrm{w}) \mathrm{H}_{2} \mathrm{O}_{2}$ and $7 \mathrm{~mL} \mathrm{HNO}_{3}$ concentrate. The mixture was digested by heating and irradiating for $60 \mathrm{~min}$ by microwave digestion system (MDS). After heating the sample at $120{ }^{\circ} \mathrm{C}$ the volume of the digested sample was set to $0.5 \mathrm{~mL}$ and dilution up to $3 \mathrm{~mL}$ with DDW. Following the instruction of Instrument operational manual provided by manufacturer, analysis of $\mathrm{Ni}, \mathrm{Co}, \mathrm{Cd}, \mathrm{Cr}$, and $\mathrm{Pb}$ was carried out using atomic absorption spectrophotometer coupled with graphite furnace assembly. The blank solutions proceeded the same way and are used for the preparation of the calibration solutions and for measurement of the blanks. Soil samples were prepared in 3 depth of surface earth $(5 \mathrm{~cm}, 50 \mathrm{~cm}$, and $100 \mathrm{~cm}$ ). In order to quantitating analyze and confirm the relationship among soil properties and heavy metal content, the correlation analysis was applied to dataset.

\section{Results and discussion}

The results of determination of heavy metals in Isfahan's industries regions show that the concentration of $\mathrm{Cr}, \mathrm{Co}, \mathrm{Ni}, \mathrm{Cd}$ and $\mathrm{Pb}$ in drinking water and soil were very low and did not exceed the permissible levels (TLV). In soil samples, all of heavy metals $(\mathrm{Cr}, \mathrm{Co}, \mathrm{Ni}, \mathrm{Cd}, \mathrm{Pb}$ ) have low concentration in accordance to EPA and WHO references. In addition, soil samples collected from the land irrigated with waste water were higher than well water. Heavy metals accumulated in the surface soil layer may migrate into the deeper layers, and consequently pose a threat of well water contamination. The parameters of pollutants depend on the type of soil and its properties. The mean of concentration of Ni, Co and $\mathrm{Cd}$ in surface soil (5.23 $\pm 0.22,8.42 \pm 0.42,0.35 \pm 0.02)$ were higher than deeper layers $(2.15 \pm 0.12,3.28 \pm 0.19,0.08 \pm$ $0.01)$, but $\mathrm{Pb}$ and $\mathrm{Cr}$ were uniform in surface and

Table 3. Permissible limits of the metals in soil and water (FAO/WHO)

\begin{tabular}{lllll|l|l|}
\hline WHO & $\mathrm{Ni}$ & $\mathrm{Co}$ & $\mathrm{Cr}$ & $\mathrm{Cd}$ & $\mathrm{Pb}$ \\
\hline Soila & $2-40$ & $0.1-50$ & $1-180$ & $0-0.2$ & $1-200$ \\
Waterb & 70.0 & 80.0 & 50.0 & 3.0 & 10.0 \\
\hline
\end{tabular}

a $\mu g g^{-1}$

${ }^{\mathrm{b}} \mu \mathrm{g} \mathrm{L} \mathrm{L}^{-1}$ 
Table 4. Mean concentration of metals in soil and water of Isfahan's oil refinery regions $(\mathrm{N}=10)$

\begin{tabular}{lllccc}
\hline \multirow{2}{*}{ Sample } & \multicolumn{2}{c}{ Average Metal } & \multicolumn{1}{c}{ Concentration a } \\
\cline { 2 - 6 } & \multicolumn{1}{c}{$\mathbf{C r}$} & Ni & \multicolumn{1}{c}{ Co } & Cd & Pb \\
\hline Waste Waterb & $95.24 \pm 4.31$ & $146.48 \pm 7.12$ & $185.48 \pm 9.03$ & $23.36 \pm 1.33$ & $11.64 \pm 0.53$ \\
Well waterb & $28.35 \pm 1.48$ & $52.12 \pm 1.86$ & $68.53 \pm 2.77$ & $0.26 \pm 0.01$ & $1.08 \pm 0.04$ \\
Soilc & $3.38 \pm 0.17$ & $3.47 \pm 0.18$ & $5.17 \pm 0.28$ & $0.13 \pm 0.006$ & $2.19 \pm 0.14$ \\
\hline
\end{tabular}

${ }^{\mathrm{a}}$ Mean of three determinations \pm confidence interval $(\mathrm{P}=0.95, \mathrm{n}=5)$

${ }^{\mathrm{b}} \mu \mathrm{g} \mathrm{L} \mathrm{L}^{-1}$

${ }^{\mathrm{c}} \mu \mathrm{g} \mathrm{g} \mathrm{g}^{-1}$

\begin{tabular}{llllll}
\hline Sample & \multicolumn{2}{l}{ Average Metal } & \multicolumn{2}{c}{ Concentration $^{{ }^{a}}$} \\
\cline { 2 - 6 } & $\mathrm{Cr}$ & $\mathrm{Ni}$ & $\mathrm{Co}$ & $\mathrm{Cd}$ & $\mathrm{Pb}$ \\
\cline { 2 - 6 } Wastewater $^{\text {a }}$ & $377.3 \pm 14.4$ & $246.3 \pm 11.8$ & $299.7 \pm 12.3$ & $67.5 \pm 4.2$ & $94.1 \pm 6.5$ \\
\hline
\end{tabular}

${ }^{\mathrm{a}} \mu \mathrm{g} \mathrm{L} \mathrm{L}^{-1}$

deeper layers of soil. Concentrations of $\mathrm{Cr}, \mathrm{Co}, \mathrm{Cd}$ and $\mathrm{Ni}$ in waste water near industrial region (were higher than well water and lead was not significant effect $(\mathrm{P}<0.05)$. The dietary limit of metals in water and soil is very important and permissible limits of the metals in soil and water have reported by FAO/ WHO [20-24] (Table 3). Mean concentration of $\mathrm{Ni}, \mathrm{Co}, \mathrm{Cr}, \mathrm{Cd}$ and $\mathrm{Pb}$ in soil, well/drinking water obtained in Table 4.

Many industries located near agricultural land in Isfahan's regions. Some of points (A, B) was near to industries regions have higher concentration of heavy metals than other points $(\mathrm{C}-\mathrm{H})$. Nickel is a toxic metal that occurs naturally in environment. Results of our study show that maximum concentration of nickel was found in waste water (246.32 $\mu \mathrm{g} \mathrm{L}^{-1}$ ) and the minimum concentration in well water and drinking water were obtained 37.43 $\mu \mathrm{g} \mathrm{L^{-1 }}$ and $8.26 \mu \mathrm{g} \mathrm{L}^{-1}$.

The mean concentration of nickel in drinking water, well water and soil were $22.12 \pm 1.86 \mu \mathrm{g}$ $\mathrm{L}^{-1}, 146.48 \pm 7.12 \mu \mathrm{g} \mathrm{\textrm {L } ^ { - 1 }}$ and $3.47 \pm 0.18 \mu \mathrm{g} \mathrm{g} \mathrm{g}^{-1}$, respectively. Cobalt is an essential micronutrient for man, animals, and plants for a range of metabolic process. However, in any case the use of cobalt supplementation has been associated with toxic side effects such as cardiomyopathy. The high concentration of cobalt in human as compare to the maximum permissible limits $\left(0.01 \mu \mathrm{g} \mathrm{g}^{-1}\right)$ can be affected on nervous system, bones, liver,

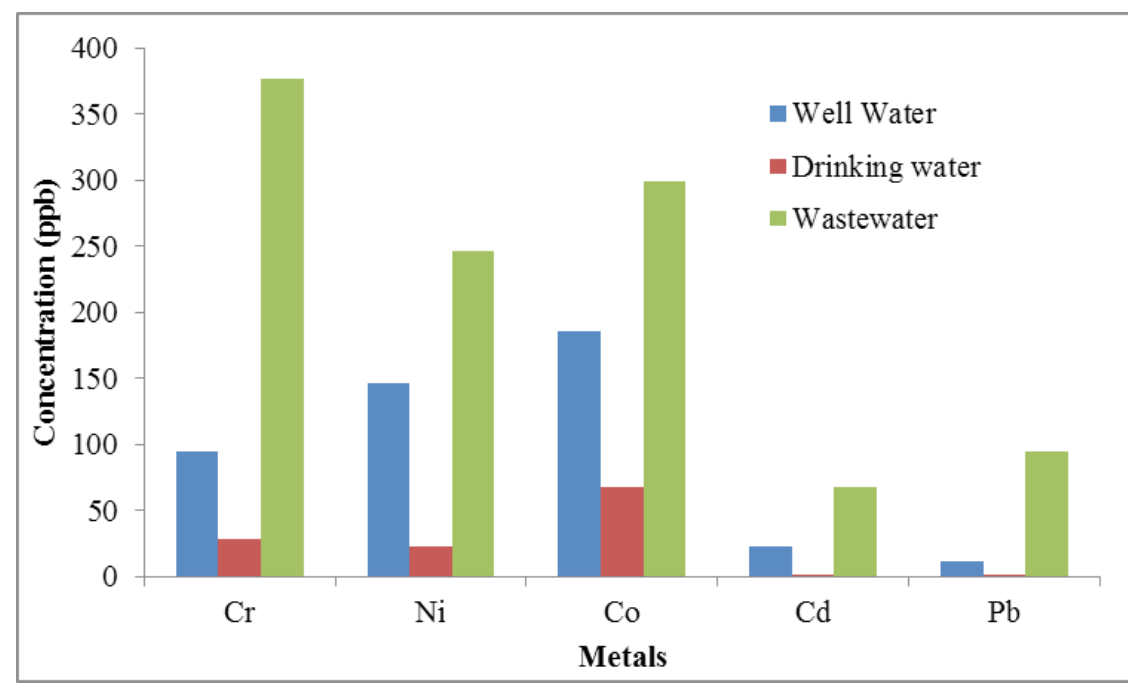

Fig. 2. Mean concentration of metals in well, drinking and waste water of Isfahan's industries regions. 


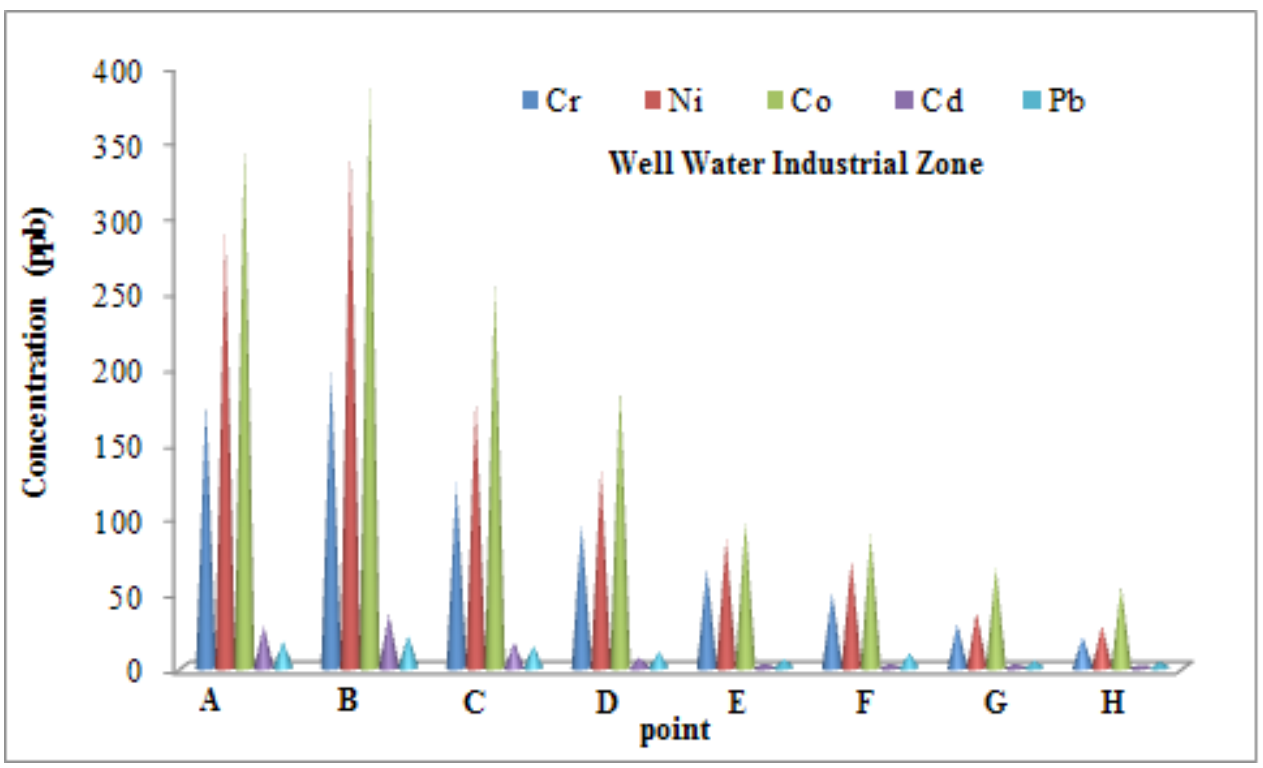

Fig. 3. Mean concentration of metals in sampling point of waste water in Isfahan's oil refinery regions.

pancreases, teeth and causes blood diseases. Results of our study show that maximum concentration of cobalt was found in waste water $\left(357.7 \mu \mathrm{g} \mathrm{L}^{-1}\right)$ and the minimum concentration in well water and soil $\left(32.12 \mu \mathrm{g} \mathrm{L}^{-1}, 0.38 \pm 0.01 \mu \mathrm{g} \mathrm{g} \mathrm{g}^{-1}\right)$. The mean concentration of cobalt in well water, waste water and soil were $185.48 \pm 9.03 \mu \mathrm{g} \mathrm{L}^{-1}, 299.7 \pm 12.3 \mu \mathrm{g}$ $\mathrm{L}^{-1}$ and $5.17 \pm 0.28 \mu \mathrm{g} \mathrm{g} \mathrm{g}^{-1}$ respectively. Cobalt and nickel have a high concentration in waste water as compared with WHO references. USEPA drinking water standard for chromium and FAO recommended the maximum limit for irrigation water as $100 \mu \mathrm{g} \mathrm{L}^{-1}$. Results of chromium show that maximum concentration was found in waste water (483.53 $\left.\mu \mathrm{g} \mathrm{L}^{-1}\right)$ and the minimum concentration in well water and soil $\left(17.09 \mu \mathrm{g} \mathrm{L}^{-1}, 1.08 \pm 0.07 \mu \mathrm{g} \mathrm{g}^{-1}\right)$. The mean concentration of $\mathrm{Cr}$ in well water, waste water and soil were $95.24 \pm 4.31 \mu \mathrm{g} \mathrm{L}^{-1}, 377.3 \pm$ $14.4 \mu \mathrm{g} \mathrm{L}^{-1}$ and $3.38 \pm 0.17 \mu \mathrm{g} \mathrm{g}^{-1}$, respectively. Speciation chromium in waste water showed that the $\mathrm{Cr}$ (VI) has high concentration than $\mathrm{Cr}$ (III) $(\mathrm{C}<65 \%)$ and in well water had more less $10 \%$. Cadmium and lead have a high concentration in waste water as compared with WHO references. In waste water, maximum / minimum concentration of $\mathrm{Cd}$ and $\mathrm{Pb}$ were found $\left(91.3 \pm 5.3 \mu \mathrm{g} . \mathrm{L}^{-1 /} 24.4\right.$ $\left.\pm 1.9 \mu \mathrm{g} . \mathrm{L}^{-1}\right)$ and $\left(135.7 \pm 7.2 \mu \mathrm{g} . \mathrm{L}^{-1} / 36.5 \pm 2.2\right.$ $\left.\mu \mathrm{g} . \mathrm{L}^{-1}\right)$, respectively. The mean of $\mathrm{Cd}$ and $\mathrm{Pb}$ in well waters, drinking waters and wastewaters was achieved $(12.37 \pm 1.33 ; 0.26 \pm 0.01 ; 67.5 \pm 4.2)$ and $(11.64 \pm 0.53 ; 1.08 \pm 0.04 ; 94.1 \pm 6.5)$, respectively.

\section{Conclusion}

In this study, the concentration of heavy metals such as $\mathrm{Cr}, \mathrm{Co}, \mathrm{Cd}, \mathrm{Pb}$, and $\mathrm{Ni}$ in soil, well water and waste water in Isfahan's industries regions were analyzed. After digestion the soil and waste water samples with microwave, the concentration of heavy metals determined by ET-AAS. The concentrations of $\mathrm{Cr}, \mathrm{Co}, \mathrm{Cd}, \mathrm{Pb}$ and $\mathrm{Ni}$ in drinking water and soil have low TLV with compared to WHO/FAO references. But the same metals except lead have high concentration in well water. Lead concentration was not significant in samples $(\mathrm{P}<0.05)$. Figure 1 showed that the A,B points have higher concentration of heavy metals than other points in Isfahan's regions. The mean concentration of $\mathrm{Cr}, \mathrm{Ni}, \mathrm{Co}, \mathrm{Cd}$, and $\mathrm{Pb}$ in well water were 95.24 $\pm 4.31,146.48 \pm 7.12,185.48 \pm 9.03,12.37 \pm 1.33$, and $11.64 \pm 0.53$, respectively. Therefore, $\mathrm{Cr}, \mathrm{Co}$, $\mathrm{Cd}$, and $\mathrm{Ni}$ in well water from these regions can probability cause pollution in environmental and humans. In addition, the concentrations of such elements in soils and well/drinking waters are less 
and near found in accordance to EPA and WHO references, respectively. Therefore, the pollution of heavy metals such as; $\mathrm{Cr}, \mathrm{Co}, \mathrm{Cd}$ and $\mathrm{Ni}$ in Isfahan industrial regions can be diffused to well waters and eluent waters and cause many problems in plants and humans.

\section{Nomenclature}

DDW: double de-ionized distil water WHO: Water Health Organization

\section{Refrences}

[1] L. Jarup, Impact of environmental pollution on health, balancing risk, Br. Med. Bull., 68 (2003) 167-182.

[2] Agency for Toxic Substances and Disease Registry (ATSDR), Interaction profile for arsenic, cadmium, chromium, and lead, (2004).

[3] National Health and Nutrition Examination Survey, Atlanta centers for disease control (ACDC), GA 30333, (2010).

[4] Agency for Toxic Substances and Disease Registry (ATSDR), Toxicological profile for Zinc (update), Atlanta, US department of public health and human services (2005) 1-2.

[5] S. Uchida, T. Keiko, H. Ikuko, Soil-to-plant transfer factors of stable elements and naturally occurring radionuclides, upland field crops collected in Japan, J. Nucl. Sci. Technol., 4 (2007) 628-640.

[6] M.Abbas, P. Zahida, Muhammad Iqbal, M. Riazuddin, S. Iqbal, A. Mubarik, R. Bhutto, Monitoring of toxic metals (cadmium, lead, arsenic and mercury) in vegetables of Sindh, Pakistan, Kathmandu University, J. Sci. Eng. Technol., 2 (2010) 60-65.

[7] G. Amrita, S. Das, S. Dhundasi, K. Das, Effect of garlic (Allium sativum) on heavy metal (Nickel II and ChromiumVI) induced alteration of serum lipid profile in male albino rats, Int. j. Environ. Res. Pub. health, 3 (2008) 147-151.

[8]A. Safavi, N. Iranpoor, N. Saghir, Safieh M. Glycerolsilica gel: a new solid sorbent for preconcentration and determination of traces of cobalt (II) ion, Anal. Chim. Acta, 569 (2006) 139-144.

[9] A. Safavi, H. Abdollahi, M. R. Hormozi Nezhad, R. Kamali, Cloud point extraction, preconcentration and simultaneous spectrophotometric determination of nickel and cobalt in water samples, Spec. Acta
A, Mol. Biomol. Spec., 12 (2004) 2897-2901.

[10] J. L. Manzoori, A. Bavili-Tabrizi, Cloud point preconcentration and flame atomic absorption spectrometric determination of cobalt and nickel in water samples, Microchim. Acta, (2003) 201-207.

[11] T. Sanders, Neurotoxic effects and biomarkers of lead exposure: a review, Rev. Environ. health, 24 (2009) 15-46.

[12] M. Jakubowski, Low-level environmental lead exposure and intellectual impairment in children, the current concepts of risk assessment, Int. j. Occup. Med. Environ. health, 24 (2011) 1-7.

[13] L. D. Wang, F. Y. Zhou, X. M. Li, L. D. Sun, X. Song, Y. Jin, J. M. Li, Genome-wide association study of esophageal squamous cell carcinoma in Chinese subjects identifies a susceptibility locus at PLCE1, Nat. Gen., 9 (2010) 759.

[14] Y. L. Liu, K. L. Luo, X. X. Li., X. Gao, R. X. Ni, S. B. Wang, X. L. Tian, Regional distribution of longevity population and chemical characteristics of natural water in Xinjiang, China Sci. Total Environ., 473, (2014), 54-62.

[15] A. H. Arias, J. Eduardo Marcovecchio, Continent Derived Metal Pollution Through Time: Challenges of the Global Ocean, Marine Pollution and Climate Change, CRC Press, (2017) 107-125.

[16] M. Krishnamurthy, P. Ramalingam, K. Perumal, L. P. Kamalakannan, J. Chinnadurai, R. Shanmugam, K. Srinivasan, V. Venugopal, Occupational heat stress impacts on health and productivity in a steel industry in southern India. Safety and health at work, (2017) 99-104.

[17] M. H. França, E. Carasek, Chromium speciation and preconcentration using zirconium (IV) and zirconium (IV) phosphate chemically immobilized onto silica gel surface using a flow system and $\mathrm{F}$ AAS, Talanta, 2 (2005) 537-542.

[18] J. Sunderman, F. William, M. Sidney Hopfer, T. Swift, W. N. Rezuke, L. Ziebka, P. Highman, B. Edwards, M. Folcik, H. R. Gossling, Cobalt, chromium, and nickel concentrations in body fluids of patients with porous-coated knee or hip prostheses, J. Orth. Res., 7 (1989) 307-315.

[19] H. Shirkhanloo, A. A. Beigi, M. M. Eskandari, B. Kalantari, Dispersive liquid-liquid microextraction based on task-specific ionic liquids for determination and speciation of chromium in human blood, J. Anal. Chem., (2015) 1448-55. 
[20] Singh S., M. Kumar, Heavy metal load of soil, water and vegetables in peri-urban Delhi, Environ. Monit. Assess., 120 (2006) 79-91.

[21] P. J. Li, X. Wang, G. Allinson, X. J. Li, X. Z. Xiong, Heavy metals, J. Hazard. Mater., 161 (2009) 516.

[22] R. K. Yadav, B. Goyal, R. K. Sharma, S. K. Dubey, P. S. Minhas, Post-irrigation impact of domestic sewage effluent on composition of soils, crops and ground water, a case study, Environ. Int. J., 28 (2002) 481-486.

[23] W. H. Liu, J. Zhao, Z. Ouyang, L. Söderlund, G. Liu., Impacts of sewage irrigation on heavy metal distribution and contamination in Beijing, China., Environ. Int. J., 31 (2005) 805-812.

[24] Muchuweti, Maud, J. W. Birkett, E. Chinyanga, R. Zvauya, Mark D. Scrimshaw, J. N. Lester, Heavy metal content of vegetables irrigated with mixtures of wastewater and sewage sludge in Zimbabwe: implications for human health, Agriculture, Ecosystems Environ., 112 (2006) 41-48.

[25] L. Schenk, S. O. Hansson, C. Rudén, M. Gilek, Occupational exposure limits: A comparative study, Reg. Toxicol. Pharm., (2008) 261-270.

[26] World Health Organization (WHO), Boron in drinking-water: Background document for development of WHO Guidelines for drinking water quality, Geneva, (2009).

[27] S. Sarkar, A.Tanveer, K. Swami, D. Christopher, B. Abdul, A. Vincent, H. Liaquat, History of atmospheric deposition of trace elements in lake sediments, J. Geophys. Res.: Atm., 11 (2015) 5658-5669.

[28] JI N. Kumar, H. Soni, R. N. Kumar, I. Bhatt, Macrophytes in phytoremediation of heavy metal contaminated water and sediments in Pariyej Community Reserve, Gujarat, India, Turkish J. Fish. Aqu. Sci., 2 (2008) 193-200.

[29] K. Mortazavi, M. Ghaedi, M. Roosta, M. Montazerozohori, Chemical functionalization of silica gel with 2-((3-silylpropylimino) methyl) phenol (SPIMP) and its application for solid phase extraction and preconcentration of $\mathrm{Fe}$ (III), $\mathrm{Pb}$ (II), $\mathrm{Cu}$ (II), Ni (II), Co (II) and Zn (II) Ions.” Indian J. Sci. Technol., 5 (2012) 1893-1900.

[30] H. Mizuguchi, T. Takahashi, A. Sasaki, S. Junichi, Ultra-trace determination of lead (ii) in water using electrothermal atomic absorption spectrometry after preconcentration by solid-phase extraction to a small piece of cellulose acetate type membrane filter, Anal. Sci., 27 (2011) 85-89.

[31] S. Z. Mohammadi, T. Shamspur, M. A. Karimi, E. Naroui. "Preconcentration of trace amounts of $\mathrm{Pb}$ (ii) ions without any chelating agent by using magnetic iron oxide nanoparticles prior to ETAAS determination, The Scientific World J., (2012).

[32] D. A. Skoog, F. J. Holler, R. Stanley, Crouch instrumental analysis, Belmont: Brooks/ Cole, Cengage Learning, 47 (2007). 